\title{
The Effectiveness of Instructional Video Media in Coffee Knowledge Courses (Baristas)
}

\author{
Syafruddin Rais ${ }^{1^{*}}$, Unung verawardina ${ }^{2}$, Wakhinuddin ${ }^{3}$, Ambiyar $^{4}$, \\ Dochi Ramadhani ${ }^{5}$ \\ ${ }^{1}$ Prodi Tata Hidang, Batam Tourism Polytecchnic, Indonesia \\ 3,4Jurusan Teknik Mesin, Universitas Negeri Padang, Padang, Indonesia \\ 2,5 Programstudi Pendidikan Teknologi Informasi dan Komputer IKIP PGRI Pontianak, Indonesia \\ e-mail: btprais@gmail.com, unungverawardina@gmail.com, ambiyar@ft.unp.ac.id, emaildochi@gmail.com
}

\begin{abstract}
This study aims to determine the effectiveness of the use of instructional video media in the coffee knowledge course (barista). In design, this was a quasi-experimental study that implemented learning methods in experimental class and control class. The sample in this study was students taking the coffee knowledge course, consisting of 22 students in the experimental class and 22 students in the control class. Instruments used were learning outcome tests and learning activity sheets. The findings showed that video media learning resulted in good learning outcomes, while conventional learning resulted in fair learning outcomes. In terms of activity, students who learned using video media were more active than those who learned in a conventional setting. It was concluded that the learning outcomes and activity of students in the experimental class were better than those in the control class, in other words, instructional video media was more effective than conventional learning for the coffee knowledge course. The novelty observed as compared to conventional learning and it showed that videos containing elements of texts, images, illustrations led instructors or lecturers to teach in a more practical way that facilitated material understanding, unlike conventional learning in which media were rarely used.
\end{abstract}

Keywords: Video Media; Learning Outcomes; Learning Activities

\section{Introduction}

Vocational education primarily aims to produce skilled and job-ready graduates. To achieve this, appropriate steps need to be taken in learning activities. Learning processes must be improved to produce competent learning outcomes. According to (Winataputra, 2007) learning is an activity conducted to initiate, facilitate, and escalate student learning intensity and quality. Therefore, learning activity constitutes inseparable interaction between educators and students. In other definition, learning means efforts to provide stimulation, guidance, instruction, and encouragement to students in learning (Chauhan, 1997). Educators are required to choose the best method, strategy, or media for the learning process. Educators should be able to implement various techniques in their teaching to improve learning outcomes (Feladi et al., 2020) and in this study, the topic of interest is learning media. Learning media may be used as an alternative learning source in learning activities (Alimah, 2012).

Well-designed learning media will greatly help students comprehend and grasp subject matter (Muhson, 2010) For this reason, media are used to convey messages, making learning processes more efficient and effective (Munadi, 2012). To date, the conventional teaching method is still widely used. It can be defined as traditional learning or lecture method because interactions between teachers and students only occur verbally (Isjani, 2009). Conventional teaching refers to an activity involving face-to-face interaction between instructors and students in a class, where students passively receive information and replicate the information in an exam (Li, 2016). Conventional learning gives rise to discrepancy or gap since students are required only to memorize and work procedurally without grasping the underlying concept (Wulansari, 2014). To overcome this gap, educators are urged to improve learning quality through reformation (Rosyidah, 2016). This reformation can be achieved through the

\footnotetext{
${ }^{*}$ Corresponding author.

Received 13 April 2020; Accepted 18 June 2020; Available online 20 June 2020

(C) 2020 JPI. All Rights Reserved
} 
implementation of new models, approaches, strategies, or learning or instructional media.

According to (Arsyad, 2007) learning media include audiovisual instruments, teaching materials, audiovisual communication, educational visual instrument, educational technology as well as teaching aids, and explanatory tools. With the use of media, efficiency and effectiveness of delivery and communication and material clarity in learning can be achieved. Lecturers as the executor of learning must be able to choose appropriate learning and according to (Asyhar, 2012) several qualities should be taken into account when choosing media, namely (1) clear and organized, (2) clean and interesting, (3) appropriate, (4) relevant to materials being taught, (5) following learning objectives, (6) practical, flexible and resilient, (7) quality, and (8) appropriate in size with the learning environment. Therefore, lecturers should apply utmost wisdom when choosing the most suitable media since not all of them are universally applicable to any courses.

Discrepancies in the use of media for learning may result from the suboptimal utilization of technology such as computers, projectors, and internet networks. It causes students to feel bored and uninterested which in turn leads to learning outcomes below minimum comprehension criteria (Hartini et al., 2017). Here, learning media in the form of video can be introduced to draw students' attention. Students can access videos to help to tackle difficult subject matter (uohua Pan et al., 2012). One form of media is a video that presents audio and visual content containing learning messages about concepts, principles, procedures, theories, and practices to help understanding learning material (Riyana, 2007).

The advantage of video media is that it can display moving images with the sound that makes it easy for students to understand the material (Smaldino et al., 2007). Another advantage of video media is its ability to visualize subject matter for students (Agustiningsih, 2015). Through the use of video media, course material can be conveyed visually, clearly, and factually.

Coffee knowledge course aims to provide an understanding of the introduction of coffee, how to choose good coffee, and how to mix coffee that emits a delicious aroma. It is a prerequisite course and must be taken by students. Expected learning outcomes are the development of students' (1) cognitive competence, meaning that students understand how to choose coffee that produces a truly delicious taste, (2) psychomotor competence, meaning that students understand how to make coffee with quality ingredients and (3) effective competence, meaning that students can analyze various types of coffee in the world through their learning activities.

Considering the characteristics of the course, a medium that can achieve better delivery of materials through illustrations, concepts, and practices is needed. The observation conducted by the researchers at Batam Tourism Polytechnic reveals various discrepancies, such as poor student learning outcomes and passive learning activities. In the class, lectures are conventional and monotonous, despite not all subject matters are necessarily suitable and effective when taught using conventional methods (Rosyidah, 2016).

Moreover, in conventional learning, teachers tend to monotonously lecture while students listen to and note down what is said by them, creating a passive environment (Wulansari, 2014). This is in line with (Devinder \& Zaitun, 2006) observation revealing that many lecturers still use conventional teaching by explaining and writing on the board. On the other hand, the coffee knowledge course requires a hands-on contextual learning experience. However, since the course does not always take place in a laboratory, learning needs to be bolstered with the use of technology that can visualize lectures about coffee. One solution to deal with the problem above is the use of video media. Through video, subjects become clearer and easier to understand (Shabiralyani et al., 2015). The images, texts, and sounds contained in the video can clarify the contents of the course both in theory and practice (Riyana, 2007).

A study by (Mayer et al., 2020) shows that the use of video can enhance learning effectiveness, while findings of (Ljubojevic et al.,2014) study show that contexts of video contents affect efficiency. Videos can also boost motivation (Bravo et al., 2011) (NikopoulouSmyrni \& Nikopoulos, 2010). (Preradović \& Jandrić, 2016) argue that future research must move towards video literacy. The purpose of this study is to determine the effectiveness of the 
use of instructional video media on the coffee knowledge course (barista), while the focus of this study is to determine the results and learning activities of students using instructional video media on said course.

\section{Method}

This study utilized the experiment method with a quasi-experimental design, involving experimental group and control group for comparison purposes. The research design used was presented in the following table.

Tabel 1. Control Group Post-test Design

\begin{tabular}{ccc}
\hline Experimental & $X_{1}$ & T1 \\
Control & $X_{2}$ & T2 \\
\hline
\end{tabular}

Description:

$\mathrm{T} 1$ and $\mathrm{T} 2=$ Post-tests

$X_{1} \quad=$ Treatment, learning using video

$X_{2} \quad=$ Treatment, learning using a conventional method

As seen in Table 1, the experimental group was treated with video media learning in the coffee knowledge course (barista), while the control group was treated with a conventional learning method. The population in this study was all first-semester students of the Food \& Beverage Management Program Study of Batam Tourism Polytechnic taking the coffee knowledge course, totaling 44 students taken using a purposive sampling technique, broken down into 22 experimental students and 22 control students. To determine the learning outcome of both groups, the data were analyzed using SPSS version 20.

\section{Results and Discussion}

\subsection{Results}

The learning outcomes of students in both groups were presented in the following table.

Tabel 1. Post-test Results of Experimental and Control Class

\begin{tabular}{lcccc}
\hline \multicolumn{1}{c}{ Class } & N & Mean & Std Deviation & $\begin{array}{c}\text { Std Error } \\
\text { Maen }\end{array}$ \\
\hline Experimental (using videos) & 22 & 73.50 & 7.469 & 1.592 \\
Control (conventional teaching) & 22 & 68.09 & 6.996 & 1.492 \\
\hline
\end{tabular}

From the pre-test data, it was known that the mean post-test value of the experimental class using video was 73.50, classified as good with a standard deviation of 7.4.69 and a standard error of 1.592. While for the mean post-test value of control class with conventional learning, the value was 68.09, classified as poor with a standard deviation of 6.996 and a standard error of 1.492. The mean value of the experimental class was higher than the control class.

The homogeneity test was intended to determine whether the data taken from the experimental and control class were homogenous. The results were as follows:

Tabel 2. Homogeneity Test Results

\begin{tabular}{lcccc}
\hline \multicolumn{1}{c}{ Results } & Levene Statistic & df1 & df2 & Sig. \\
\hline Based on Mean & .365 & 1 & 42 & .549 \\
Based on Median & .217 & 1 & 42 & .644 \\
Based on Median and with adjusted df & .217 & 1 & 41.872 & .644 \\
Based on trimmed mean & .352 & 1 & 42 & .556 \\
\hline
\end{tabular}


The table above showed the results of the homogeneity test using SPSS. The post-test data were declared homogenous as seen from based on the mean value of learning results of 0.365 , which was $>0.050$. This meant that both data were homogenous.

Next was the normality test to determine whether the post-test data obtained were normal.

Tabel 3. Normality Test Results

\begin{tabular}{lccc}
\hline \multicolumn{1}{c}{ Class } & Statistik & df & Sig \\
\hline Experimental (using videos) & .136 & 22 & .200 \\
Kontrol (conventional teaching) & .126 & 22 & .200 \\
\hline
\end{tabular}

The table above showed that the value of both classes was 0.200 , higher than 0.50 . Thus, it can be concluded that the post-test data were normally distributed. Next was a t-test to prove the hypothesis and identify differences between the two classes. Below were the results.

Tabel 4. T-test Results

\begin{tabular}{lccc}
\hline \multirow{2}{*}{\multicolumn{1}{c}{ Learning Outcome }} & \multicolumn{3}{c}{ Levene's test for equality of variances } \\
\cline { 2 - 3 } & F & Sig & T \\
\hline Equal variances assumed & .365 & .549 & 2.479 \\
Equal variances not assumed & & & 2.479 \\
\hline
\end{tabular}

The table above showed that from the calculation, the $F_{\text {count }}$ of Levene test was 0.356 with sig of $0.549>0.05$, thus having the same variance. Therefore, Ha was accepted and Ho was rejected, which meant that there were differences in the learning outcomes between the two classes. Using video media for learning was proven to be more effective than conventional teaching.

The summary of the test results was presented in the following table.

Tabel 5. Summary of Prerequisite Tests

\begin{tabular}{lccc}
\multicolumn{1}{c}{ Class Group } & Normality Test & Homogeneity Test & T-test \\
\hline $\begin{array}{l}\text { Experimental } \\
\text { Control }\end{array}$ & Normal & Homogenous & Reject HO \\
\hline
\end{tabular}

From Table 7, it can be concluded that the data in the experimental class and the control class were normally distributed and homogeneous. T-test results also showed that there were differences in both learning methods, where the video media method was slightly better than the conventional method. This may be due to the changes in the learning process where the lecturer was no longer the center of attention. This was in line with Rusman et al. (2012) argument saying that video media were able to simulate real-world conditions and affect feelings and emotions.

Activities in the class were also being observed. Students were considered to be active if the percentage of active behaviors was greater than passive behaviors. Indicators of student learning activities assessed were asking questions, answering questions, expressing opinions, and working on problems. The summary of the percentage of student learning activities in both classes was presented in the following table. 
Tabel 6. Summary of The Observation of Student Learning Activities

\begin{tabular}{lcccc}
\hline & \multicolumn{2}{c}{ Experimental class } & \multicolumn{2}{c}{ Control class } \\
\cline { 2 - 5 } & Active & Passive & Active & Passive \\
\hline Observation points & 14 & 14 & 14 & 14 \\
Percentage & $1.066,8 \%$ & $333,2 \%$ & $978,9 \%$ & $421,1 \%$ \\
Mean percentage & $76,2 \%$ & $23,8 \%$ & $69,9 \%$ & $30,1 \%$ \\
\hline
\end{tabular}

Based on the table above, the mean percentage of active students in the experimental class was $76.2 \%$ and $23.8 \%$ for passive students. In the control class, the mean percentage of active students was $69.9 \%$ and $30.1 \%$ for passive students. From the results, it could be concluded that students were more active in the class with video learning than conventional teaching.

\subsection{Discussion}

Learning activities are inseparable from the role of a lecturer as the one who teaches and a student as the one who is taught. Lecturers must be able to implement innovative learning methods, especially in the era of the industrial revolution 4.0 which relies heavily on the role of technology, making the use of video media in learning processes all the more important. There is a perceived shift from conventional teaching to the technological one. As mentioned above, conventional teaching creates a gap, and as stated by (Puspitarini \& Hanif, 2019) conventional learning does not interest students so they have difficulty understanding the material presented. According to (Sanjaya, 2006) in the conventional method, students are positioned as a study object, making them passive since all they do is receive information. Encouraging them to be active is a challenge in its own right. On the other hand, teachers become the center of attention making it difficult for students to learn independently (Ibrahim, 2007)

Therefore, according to (Sanaky, 2009) innovative learning media need to be utilized to overcome the limitations of the conventional learning process. Teachers can choose technology that is packaged as such in the form of instructional media. The emergence of the media strongly supports the success of learning processes because it can clarify teaching material contextually and can boost student motivation. Learning media can optimize the process of teaching and learning, foster and concretize concepts, and motivate students to learn more actively (Karo-Karo \& Rohani, 2018).

Videos are one of the emergent media in field education. According to (Daryanto, 2012) videos are a very effective medium to help the learning process, both for mass, individual, and group learning. For instructional videos to become interesting, instructors need to take into account three elements for designing and implementing videos, namely cognitive load, noncognitive elements that affect involvement through activities, and features that promote active learning (Brame, 2015). Learning effectiveness is directly proportional to the achievement of learning goals (Yousef et al., 2014; Mendoza et al., 2015)

According to (Brame, 2015) in higher education, the implementation of video media can improve effectiveness such as good cognitive outcomes and bring about the active involvement of students in learning. For the coffee knowledge course being studied here, the contextual learning experience is paramount that it requires media that can clearly illustrate, describe, and conceptualize (Tyler et al., 2009). The glaring problem in Batam Tourism Polytechnic is a conventional way of teaching that leads to passive students. According to (Brame, 2015) one media that can be used to communicate learning materials is video. Video learning can create effective learning processes (Allen \& Smith, 2012; Ibrahim et al., 2012). In addition, the gap resulting from conventional teaching cannot explain content materials (Devinder \& Zaitun, 2006).

In this study, video media is used in the coffee knowledge course to make the learning process more effective with excellent learning outcomes and activities, while at the same time to overcome the shortcomings of conventional teaching. Since videos can display moving 
pictures with sound, students can immerse themselves as if they are really at the same location as the video and to illustrate an event, making learning materials clearer in the process (Shabiralyani et al., 2015). The use of videos can increase the effectiveness of learning (Mayer, et al., 2020). Videos can display contents repeatedly and can be used as a document or reference for lecturers and campuses or used as meaningful learning media. Well-designed videos can evoke students' interest and motivate them (Bravo et al., 2011). In the experimental class, the video media used contained the subject matter of coffee knowledge course (barista) which discussed the history and development of coffee businesses, plant physiology, types of coffee, conditions, and locations for growing plants, maintenance, methods of processing coffee beans, roasting, assessment coffee quality, coffee equipment, coffee blending art, extraction methods and parameters, coffee serving techniques, and processed coffee drinks. The materials were presented in the form of texts, figures, and illustrations through videos. Instructors elaborated on the contents of the material along with the sound from the video. By using videos, students can see firsthand the concepts, facts, and applications. In line with (Taniady, 2016) study stating that videos can provide material comprehension. In addition, they facilitate theory learning and practicum in the laboratory. While in the conventional class, materials are delivered through lectures without any instructional media.

After both methods were implemented in both classes, the next step was post-test. The post-test was given to determine students' learning outcomes after the treatments with test questions following the course (coffee knowledge (barista)). In addition, the researchers also evaluated student activities during the learning process based on several indicators, such as asking questions, answering questions, expressing opinions, and working on problems. Based on the research results, $73.50 \%$ of students in the experimental class recorded good learning outcomes compared to $63.09 \%$ of students in the control class. In terms of activity, $76.2 \%$ of students in the experimental class were considered active students, compared to $69.9 \%$ in the control class.

It could be concluded that when video media was used, students displayed better learning outcomes and activities compared to the conventional method in the control class, meaning that video media learning was more effective than conventional learning. The findings of this study managed to make learning more effective, leading to better learning outcomes and activities. This was in line with (Mayer et al., 2020) findings showing that the use of videos increased learning effectiveness. Through videos, students' learning outcomes and skills improve (Preradović \& Jandrić, 2016). The level of effectiveness in delivering material with videos for learning for students was quite high (Mendoza et al., 2015) Videos were beneficial in enhancing students' cognitive and psychomotor skills (Allen \& Smith, 2012). The novelty found was compared to conventional learning, and it was proven that videos with elements of texts, images, illustrations made tutors or lecturers provide practical explanations, making it easier to understand the material in the coffee knowledge course, compared to conventional learning without using any kind of media.

\section{Conclusions and Recommendations}

Referring to the results, the learning outcomes of students taught with video media are considered good, while the learning outcomes of students taught using the conventional method are considered fair. In terms of activity, students taught with video media are considered active, while students taught using the conventional method are considered fairly active. Therefore, it can be concluded that the learning outcomes and activities of the experimental class are higher than those of the control class for the coffee knowledge course (barista). Based on the results, in utilizing video media, lecturers need to take into account the images, texts, illustrations, and sounds contained in videos to make students more actively involved during learning activities 


\section{Acknowledgement}

The researchers would like to express their utmost gratitude to anyone who contributed to the completion of this study, to the Food \& Beverage Management Study Program, to Batam Tourism Polytechnic, to Mechanical Engineering Study Program of Universitas Negeri Padang, Postgraduate Program of Technological and Vocational Education of the Faculty of Engineering of Universitas Negeri Padang and students of the coffee knowledge course for their participation as the research subject.

\section{Reference}

Agustiningsih, A. (2015). Video Sebagai Alternatif Media Pembelajaran Dalam Rangka Mendukung Keberhasilan Penerapan Kurikulum 2013 di Sekolah Dasar. Pedagogia: Jurnal Pendidikan, 4(1), 50-58.

Alimah, S. (2012). Pengembangan Multimedia Pembelajaran Embriogenesis Hewan untuk Mengoptimalkan Pemahaman Kognitif Mahasiswa. Jurnal Pendidikan IPA Indonesia, 1(2), 131-140.

Allen WA \& Smith AR. (2012). Effects of video podcasting on psychomotor and cognitive performance, attitudes and study behavior of student physical therapists. Innovations in Education and Teaching International, 49, 401-414.

Arsyad, A. (2007). Media Pembelajaran. PT Raja Grafindo Persada.

Asyhar, R. (2012). Kreatif Mengembangkan Media Pembelajaran. Referensi.

Brame, C. J. (2015). Effective educational videos. Vanderbilt University Center for Teaching.

Bravo, E., Amante, B., Simo, P., Enache, M., \& Fernandez, V. (2011). Video as a new teaching tool to increase student motivation. In 2011 IEEE Global Engineering Education Conference (EDUCON), 638-642.

Chauhan, T. C. (1997). Patent No. 5,613,980.

Daryanto. (2012). Media Pembelajaran. PT. Sarana Tutorial Nurani Sejahtera.

Feladi, V., Hendriyani, Y., Dewi, I. P., Darni, R., \& Verawardina, U. (2020). The Profile of Technological Pedagogical and Content Knowledge of Information and Communication Technology Teachers. Test Engineering \& Management, 83, 1666-1673.

Hartini, S., Misbah, M., Dewantara, D., Oktovian, R. A., \& Aisyah, N. (2017). Developing learning media using online prezi into materials about optical equipments. Jurnal Pendidikan IPA Indonesia, 6(2), 313-317.

Ibrahim, I. (2007). Perpaduan Model Pembelajaran Aktif Konvensional (Ceramah) Dengan Cooperatif (Make-A Match) Untuk Meningkatkan Hasil Belajar Pendidikan Kewarganegaraan. Suara Guru, 3(2), 199-212.

Ibrahim M, Antonenko PD, Greenwood CM, and W. D. (2012). Effects of segmenting, signalling, and weeding on learning from educational video. Learning, Media and Technology, 37(3), 220-235.

Isjani. (2009). Pembelajaran Kooperatif. Pustaka Belajar.

Karo-Karo, I. R., \& Rohani, R. (2018). Manfaat Media Dalam Pembelajaran. AXIOM: Jurnal Pendidikan Dan Matematika, 7(1).

$\mathrm{Li}, \mathrm{Y}$. W. (2016). Transforming conventional teaching classroom to learner-centred teaching classroom using multimedia-mediated learning module. Nternational Journal of Information and Education Technology, 6(2), 105-112.

Ljubojevic, M., Vaskovic, V., Stankovic, S., \& Vaskovic, J. (2014). Using supplementary video in multimedia instruction as a teaching tool to increase efficiency of learning and quality of experience. International Review of Research in Open and Distributed Learning, 15(3), 275-291.

Mayer, R. E., Fiorella, L., \& Stull, A. (2020). Five ways to increase the effectiveness of instructional video. Educational Technology Research and Development, 1-6.

Mendoza, G. L. L., Caranto, L. C., \& David, J. J. T. (2015). Effectiveness of video presentation to students' learning. International Journal of Nursing Science, 5(2), 81-86.

Muhson, A. (2010). Pengembangan Media Pembelajaran Berbasis Teknologi Informasi. Jurnal Pendidikan Akuntansi Indonesia, 8(2), 1-10.

Munadi, Y. (2012). Media Pembelajaran. Gaung Persada Press Jakarta. 
Nikopoulou-Smyrni, P., \& Nikopoulos, C. (2010). Evaluating the impact of video-based versus traditional lectures on student learning. Educational Research (, 1(8), 304-311. https://bura.brunel.ac.uk/bitstream/2438/4652/1/Fulltext.pdf

Preradović, N. M., \& Jandrić, P. (2016). Using Video Journals In Academic Service-Learning Video Dnevnici U Akademskom Društveno Korisnom Učenju. Polytechnic \& Design, 4(4).

Puspitarini, Y. D., \& Hanif, M. (2019). Using Learning Media to Increase Learning Motivation in Elementary School. Anatolian Journal of Education, 4(2), 53-60.

Riyana, C. (2007). Pedoman Pengembangan Media Video. Universitas Pendidikan Indonesia.

Rosyidah, U. (2016). Pengaruh model pembelajaran kooperatif tipe jigsaw terhadap hasil belajar matematika siswa kelas VIII SMP Negeri 6 Metro. SAP (Susunan Artikel Pendidikan), 1(2).

Rusman dkk. (2012). Model-Model Pembelajaran. Raja Grafindo Persada.

Devinder \& A. B. Zaitun. (2006). Mobile learning in wireless classrooms. Malaysian Online Journal of Instructional Technology (MOJIT), 3(2), 26-42.

Sanaky, H. A. (2009). Learning media. Safiria Insania Press.

Shabiralyani, G., Hasan, K. S., Hamad, N., \& Iqbal, N. (2015). Impact of Visual Aids in Enhancing the Learning Process Case Research. Istrict Dera Ghazi Khan. Journal of Education and Practice, 6(19), 226-233.

Smaldino, S.E, Lowther, D.L, Russell, J. . (2007). Instructional Technology and Media for Learning (9th Ed). Pearson Prentice Hall.

Sugiyono. (2011). Metode Penelitian Kuantitatif, Kualitatif dan R\&D. Afabeta.

Taniady, V. (2016). Pengaruh Penggunaan Media Audio Visual Terhadap Pemahaman Konsep Peserta Didik Dalam Pembelajaran Geografi. Penelitian Eksperimen Kuasi Pada Kelas X SMA Labschool UPI Bandung (Doctoral dissertation, Universitas Pendidikan Indonesia).

Tyler, C. L., Anderson, M. H., \& Tyler, J. M. (2009). Giving students new eyes: The benefits of having students find media clips to illustrate management concepts. Journal of Management Education, 33(4), 444-461.

uohua Pan, G., Sen, S., Starrett, D. A., Bonk, C. J., Rodgers, M. L., Tikoo, M., \& Powell, D. V. (2012). Instructor-Made Videos as a Learner Scaffolding Tool. Instructor, 8(4).

Sanjaya, W. (2006). Strategi Pembelajaran. Kencana Prenada Media Group.

Winataputra, U. S. (2007). Teori Belajar dan Pembelajaran. Pusat Penerbitan Universitas Terbuka.

Wulansari, A. D. (2014). Efektivitas Penerapan Metode Pembelajaran Student Teams Achievement Divisions Dan Team Assisted Individualization Pada Materi Regresi Linier. Jurnal Kependidikan Dan Kemasyarakatan, 12(1), 155-173.

Yousef, A. M. F., Chatti, M. A., \& Schroeder, U. (2014). The state of video-based learning: A review and future perspectives. Int. J. Adv. Life Sci, 6(3), 122-135. 